\title{
Effect of Rabbit Compost and NPK on The Growth and Yield of Zucchini (Cucurbita Pepo L.)
}

\author{
I Putu Tommy Saputra Adi ${ }^{1}$, Made Sri Yuliartini ${ }^{2}$, I Gusti Bagus Udayana ${ }^{3}$ \\ ${ }^{1}$ Agrotechnology Study Program, Faculty of Agriculture, Warmadewa University, Indonesia \\ ${ }^{1}$ E-mail: tomilv18@gmail.com \\ ${ }^{3}$ E-mail: bagusudayana64@gmail.com
}

\begin{abstract}
This study aims to determine the effect of the dose of rabbit compost and NPK fertilizer on the growth and yield of zucchini plants. The design used in this study was a factorial randomized block design (RBD) consisting of 2 factors, namely: The first factor is rabbit compost $(\mathrm{K})$ which consists of 4 levels of treatment $\left(0,10,20\right.$, and 30 ton $\left.\mathrm{ha}^{-1}\right)$. The second factor, NPK pearl fertilizer dosage (D) consists of 4 levels $(0,100,200$, and $\left.300 \mathrm{~kg} \mathrm{ha}^{-1}\right)$. Thus, there were 16 combination treatments, each of which was repeated 3 times so that there were 48 experimental plots. The research data were analyzed statistically using analysis of variance. For a single treatment that has a real to very real effect, it is followed by the LSD test at 5\% level, the results showed that the interaction between rabbit compost dose and NPK had no significant effect on all variables. The highest fresh fruit weight was obtained at the rabbit compost dose of 30 tons ha $^{-1}$, namely $2463.64 \mathrm{~g}$, an increase of $16.09 \%$ when compared to the treatment without compost, namely $2084.30 \mathrm{~g}$. The highest fruit fresh weight was obtained at the NPK fertilizer dose of $300 \mathrm{~kg} \mathrm{ha}^{-1}$, namely $2488.95 \mathrm{~g}$. The fresh weight of the fruit increased by $18.23 \%$ when compared to the NPK fertilizer dose of 0 ton $\mathrm{ha}^{-1}$, which was $2104.87 \mathrm{~g}$.
\end{abstract}

Keywords: Zukini, Rabbit Compost Fertilizer, NPK Dosage

\section{Introduction}

Zucchini (Cucurbita pepo L.) is an annual vegetable crop that is included in the cucurbitae family, zucchini has high economic value and is still rarely cultivated by farmers. The demand for zucchini tends to increase along with the emergence of restaurants serving zucchini-based foods. The availability of sufficient nutrients in the soil is one of the factors that support the growth and development of zucchini plants. A plant that is deficient in nutrients, causes stunted plant growth. So that fertilizer application needs to be done to meet the nutrient deficiency [1].

Each plant requires a different amount of nutrients. Applying inappropriate fertilizers will cause the plants to not grow and produce optimally. Besides, giving excessive fertilizers is a waste of energy and costs (inefficient). Excessive fertilizers will cause poisoning to plants and can lead to inhibition of plant growth rates even if in a continuous state it will cause plant death [2].

Rabbit compost contains the highest nitrogen content compared to other livestock manure. According to [3], fresh rabbit manure contains $2.4 \%$ nitrogen; $\mathrm{P}$ content of $1.4 \%$; and $\mathrm{K}$ content of $0.6 \%$. For other livestock manure such as cow dung, the nitrogen content is only $0.4 \%$; goat manure $0.6 \%$ and chicken manure by $1 \%$.

According to [3] combining organic and inorganic fertilizers can also provide maximum results for plant growth. such as a combination of rabbit compost and NPK Wasp. Compost has several advantages compared to chemical fertilizers, namely it helps neutralize soil $\mathrm{pH}$, helps neutralize toxins due to the presence of heavy metals in the soil, improves soil structure to become looser and directly increases the availability of groundwater, helps the absorption of nutrients from added chemical fertilizers [4]. NPK Mutiara fertilizer (16:16:16) is one of the compound inorganic 
fertilizers which has $16 \%$ macronutrients $\mathrm{N}, \mathrm{P}$, and $\mathrm{K}$ respectively [5]. This fertilizer is very good for supporting plant growth. Besides, the advantage is that the nutrients donated can meet plant nutrient needs [4].

According to the results of the study [6], the highest economic fresh weight was obtained at the dose of rabbit manure 30 tons ha ${ }^{-1}$, namely $105.72 \mathrm{~g}$, an increase of $70.35 \%$ when compared to the economic fresh weight with a dose without rabbit manure, namely $62.06 \mathrm{~g}$. In a study by [7], compost treatment from cow manure of 20 tons ha- ${ }^{-1}$ and NPK phonska $300 \mathrm{~kg} \mathrm{ha}^{-1}$ could increase the growth of maize plants. This study aims to determine the effect of rabbit compost dose, NPK fertilizer dosage, and its combination on the growth and yield of zucchini while the hypothesis proposed in this study is the provision of a dose of 30 tons ha $^{-1}$ of rabbit compost and fertilizer dose. NPK $300 \mathrm{~kg}$ $\mathrm{ha}^{-1}$ can increase the growth and yield of zucchini plants.

\section{Materials and Methods}

\subsection{Research Design}

This research design used in this study was a factorial randomized block design (RBD) consisting of 2 factors, namely: The first factor is rabbit compost $(\mathrm{K})$ which consists of 4 levels of treatment, namely: $\mathrm{K} 0=0$ ton ha ${ }^{-1}, \mathrm{~K} 1=10$ ton ha- ${ }^{-1}, \mathrm{~K} 2=20$ ton ha ${ }^{-1}, \mathrm{~K} 3=30$ ton ha ${ }^{-1}$. While the second factor the dose of NPK fertilizer (D) consists of 4 levels, namely: D0 $=0 \mathrm{~kg} \mathrm{ha}^{-1}, \mathrm{D} 1=100$ $\mathrm{kg} \mathrm{ha}^{-1}, \mathrm{D} 2=200 \mathrm{~kg} \mathrm{ha}^{-1}, \mathrm{D} 3=300 \mathrm{~kg} \mathrm{ha}^{-1}$. Thus, there were 16 combination treatments, each of which was repeated 3 times so that there were 48 experimental plots.

\subsection{Research Time and Place}

This research was conducted in the rice fields at Banjar Tundak, Mekarsari Village, Baturiti District, Tabanan Regency, Denpasar, Bali with an altitude of 300-990 m above sea level, with a temperature range of $24-26^{\circ} \mathrm{C}$ and this research activity was carried out from 26 February to 22 May 2020.

\subsection{Research Materials and Tools}

The materials used in this study were Zukini seeds of Jacky Z-6 variety, rabbit compost, NPK Tawon fertilizer (16:16:16). The tools used in this research are a hoe, sickle, raffia rope, knife, machete, length measuring instrument, weight measuring instrument, plastic bag, bamboo, tugal, stationery, and documentation.

\subsection{Research Variables}

The variables observed in this study included maximum plant height, the maximum number of leaves, fresh weight per fruit, number of fruit harvested, fruit length, fruit diameter, plant oven-dry weight, fruit oven-dry weight, and harvest index.

The data obtained from the research results were analyzed using a variance. If the results of variance on the treatment had no significant effect $(\mathrm{P}>0.05)$ then no further test was carried out, but if the results of variance on the treatment had a significant effect $(\mathrm{P}<0.05)$ then to compare the two treatment averages was carried out with the Least Significant Difference (LSD) test with a level of $5 \%$. 


\section{Results and Discussion}

The results of the statistical analysis of the observed variables in the treatment of rabbit compost and wasp NPK and their interactions are presented in Table 1.

Table 1

Significant Effect of Rabbit Compost and NPK Fertilizer Dosage on the Growth and Yield of Zukini

\begin{tabular}{llccc}
\hline No & Variable & \multicolumn{3}{c}{ Treatment Dosage } \\
\cline { 3 - 5 } & & $\begin{array}{c}\text { Compost } \\
(\mathrm{K})\end{array}$ & $\begin{array}{c}\text { NPK } \\
(\mathrm{D})\end{array}$ & $\begin{array}{c}\text { Interaction } \\
(\mathrm{KxD})\end{array}$ \\
\hline 1 & Maximum Plant Height & $\mathrm{ns}$ & $\mathrm{ns}$ & $\mathrm{ns}$ \\
2 & Maximum Number of Leaves & $\mathrm{ns}$ & $\mathrm{ns}$ & $\mathrm{ns}$ \\
3 & Amount of Harvest per Plant & $*$ & $*$ & $\mathrm{~ns}$ \\
4 & Fresh Fruit Weight & $* *$ & $* *$ & $\mathrm{~ns}$ \\
5 & Fruit Length & $\mathrm{ns}$ & $\mathrm{ns}$ & $\mathrm{ns}$ \\
6 & Fruit Diameter & $\mathrm{ns}$ & $\mathrm{ns}$ & $\mathrm{ns}$ \\
7 & Fruit Oven Dry Weight & $\mathrm{ns}$ & $\mathrm{ns}$ & $\mathrm{ns}$ \\
8 & Oven Dry Weight is Stable & $* *$ & $\mathrm{~ns}$ & $\mathrm{~ns}$ \\
9 & Harvest Index & $*$ & $\mathrm{~ns}$ & $\mathrm{~ns}$ \\
\hline Information : ns = no significant effect $(\mathrm{P}>0.05)$ & \\
$*$ & $=$ Significantly affected (P<0.05) & & \\
$* *$ & $=$ Very significant effect $(\mathrm{P}<0.01)$ &
\end{tabular}

Table 2

Average of All Plant Variables Observed in Dose Treatment of Rabbit Compost (K)

\begin{tabular}{|c|c|c|c|c|c|}
\hline \multirow[b]{2}{*}{ Treatment } & \multicolumn{5}{|c|}{ Rabbit Compost (K) } \\
\hline & $\begin{array}{l}0 \text { ton ha }{ }^{-1} \\
\text { (K0) }\end{array}$ & $\begin{array}{l}10 \text { ton }^{-1} \mathrm{~h}^{-1} \\
(\mathrm{~K} 1)\end{array}$ & $\begin{array}{l}20 \text { ton } \mathrm{ha}^{-1} \\
\text { (K2) }\end{array}$ & $\begin{array}{l}30 \text { ton }^{-1} \mathrm{ha}^{-1} \\
(\mathrm{~K} 3)\end{array}$ & $\begin{array}{l}\text { LSD } \\
5 \%\end{array}$ \\
\hline Plant height $(\mathrm{cm})$ & $35.4 \mathrm{a}$ & $34.31 \mathrm{a}$ & $36.45 \mathrm{a}$ & $34.63 \mathrm{a}$ & - \\
\hline Number of leaves (strands) & $19.33 \mathrm{a}$ & $18.08 \mathrm{a}$ & $17.88 \mathrm{a}$ & $19.17 \mathrm{a}$ & - \\
\hline Number of harvests (fruit) & $8.50 \mathrm{~b}$ & $8.83 \mathrm{ab}$ & $8.63 \mathrm{~b}$ & $9.21 \mathrm{a}$ & 0.42 \\
\hline Fruit fresh weight $(\mathrm{g})$ & $2084.30 \mathrm{~b}$ & $2356.87 \mathrm{a}$ & $2357.98 \mathrm{a}$ & $2463.64 \mathrm{a}$ & 169.26 \\
\hline Fruit length $(\mathrm{cm})$ & $19.39 \mathrm{a}$ & $19.64 \mathrm{a}$ & $19.65 \mathrm{a}$ & $19.95 \mathrm{a}$ & - \\
\hline Fruit diameter $(\mathrm{cm})$ & $14.68 \mathrm{a}$ & $14.54 \mathrm{a}$ & $14.48 \mathrm{a}$ & $14.42 \mathrm{a}$ & - \\
\hline Fruit oven-dry weight (g) & $13.83 \mathrm{a}$ & $13.63 \mathrm{a}$ & $14.15 \mathrm{a}$ & $13.85 \mathrm{a}$ & - \\
\hline Staged oven-dry weight (g) & $46.05 \mathrm{a}$ & $42.32 \mathrm{~b}$ & $47.83 \mathrm{a}$ & $48.37 \mathrm{a}$ & 3.54 \\
\hline Harvest index & $24.18 \mathrm{a}$ & $25.21 \mathrm{a}$ & $22.75 \mathrm{ab}$ & $20.86 \mathrm{~b}$ & 3.07 \\
\hline
\end{tabular}

Note: The average value followed by the same letter in the same treatment and the same column means that there is no significant difference in the LSD 5\%

Table 3

Average of All Plant Variables Observed in NPK Fertilizer Dose Treatment (D)

\begin{tabular}{|c|c|c|c|c|c|}
\hline \multirow[b]{2}{*}{ Treatment } & \multicolumn{5}{|c|}{ NPK Pearl (M) } \\
\hline & $\begin{array}{l}0 \mathrm{~kg} \mathrm{ha}^{-1} \\
\text { (D0) }\end{array}$ & $\begin{array}{l}100 \mathrm{~kg} \mathrm{ha}^{-1} \\
\text { (D1) }\end{array}$ & $\begin{array}{l}200 \mathrm{~kg} \mathrm{ha}^{-1} \\
\text { (D2) }\end{array}$ & $\begin{array}{l}300 \mathrm{~kg} \mathrm{ha}^{-1} \\
\text { (D3) }\end{array}$ & LSD $5 \%$ \\
\hline Plant height $(\mathrm{cm})$ & $35.27 \mathrm{a}$ & $34.1 \mathrm{a}$ & $37.03 \mathrm{a}$ & $34.4 \mathrm{a}$ & - \\
\hline Number of leaves (strands) & $17.92 \mathrm{a}$ & $19.38 \mathrm{a}$ & $19.17 \mathrm{a}$ & $18.00 \mathrm{a}$ & - \\
\hline Number of flowers (florets) & $8.42 \mathrm{~b}$ & $8.42 \mathrm{~b}$ & $8.75 \mathrm{ab}$ & $9.00 \mathrm{a}$ & 0.42 \\
\hline Fruit fresh weight $(\mathrm{g})$ & $2104.87 \mathrm{~b}$ & $2346.88 \mathrm{a}$ & $2322.09 \mathrm{a}$ & $2488.95 \mathrm{a}$ & 169.26 \\
\hline Fruit length $(\mathrm{cm})$ & $19.72 \mathrm{a}$ & $19.58 \mathrm{a}$ & $19.72 \mathrm{a}$ & $19.59 \mathrm{a}$ & - \\
\hline Fruit diameter $(\mathrm{cm})$ & $14.61 \mathrm{a}$ & $14.45 \mathrm{a}$ & $14.56 \mathrm{a}$ & $14.50 \mathrm{a}$ & - \\
\hline Fruit oven-dry weight (g) & $13.40 \mathrm{a}$ & $13.77 \mathrm{a}$ & $13.88 \mathrm{a}$ & $14.41 \mathrm{a}$ & - \\
\hline Staged oven-dry weight (g) & $46.57 \mathrm{a}$ & $46.88 \mathrm{a}$ & $45.86 \mathrm{a}$ & $45.26 \mathrm{a}$ & - \\
\hline Harvest index & $25.21 \mathrm{a}$ & $22.91 \mathrm{a}$ & $21.35 \mathrm{a}$ & $23.53 \mathrm{a}$ & - \\
\hline
\end{tabular}

Note: The average value followed by the same letter in the same treatment and the same column means that there is no significant difference in the LSD 5\% 
The results of statistical analysis showed that the interaction between rabbit compost dose and NPK fertilizer dose $(\mathrm{KxD})$ had no significant effect $(\mathrm{P} \geq 0.05)$ on all variables. The highest fresh fruit weight was obtained at the dose of rabbit compost 30 tons ha $^{-1}$ (K3), namely $2463.64 \mathrm{~g}$, an increase of $16.09 \%$ when compared to the treatment without compost dose 0 tons ha ${ }^{-1}$ (K0), namely 2084.30 g. The high fresh weight was supported by the number of crops per cropped $(\mathrm{r}=0.821 *)$, fruit length $\left(\mathrm{r}=0.935^{* *}\right)$ and fruit diameter $(\mathrm{r}=-0.975 * *)($ Table 4$)$.

Table 4

. Correlation coefficient value between plant variables (r) due to the influence of rabbit compost dose (K)

\begin{tabular}{|c|c|c|c|c|c|c|c|c|c|}
\hline & 1 & 2 & 3 & 4 & 5 & 6 & 7 & 8 & 9 \\
\hline 1 & 1 & & & & & & & & \\
\hline 2 & $-0.296 n s$ & 1 & & & & & & & \\
\hline 3 & $-0,609 n s$ & $0.176 \mathrm{~ns}$ & 1 & & & & & & \\
\hline 4 & $-0,243 n s$ & $-0,382 \mathrm{~ns}$ & $0.821 *$ & 1 & & & & & \\
\hline 5 & $-0.328 n s$ & $-0.032 \mathrm{~ns}$ & $0.942 * *$ & $0.935 * *$ & 1 & & & & \\
\hline 6 & $0.062 \mathrm{~ns}$ & $0.340 \mathrm{~ns}$ & $-0.773 *$ & $-0,975 * *$ & $-0,936 * *$ & 1 & & & \\
\hline 7 & $0.932 * *$ & $-0.249 \mathrm{~ns}$ & $-0.281 \mathrm{~ns}$ & $0.065 \mathrm{~ns}$ & $0.029 \mathrm{~ns}$ & $-0.266 n s$ & 1 & & \\
\hline 8 & $0.541 \mathrm{~ns}$ & $0.320 \mathrm{~ns}$ & $0.203 \mathrm{~ns}$ & $0.199 \mathrm{~ns}$ & $0.385 \mathrm{~ns}$ & $-0,401 \mathrm{~ns}$ & $0.762 \mathrm{~ns}$ & 1 & \\
\hline 9 & $-0.155 n s$ & $-0.314 \mathrm{~ns}$ & $-0,628 \mathrm{~ns}$ & $-0.555 n s$ & $-0.752 \mathrm{~ns}$ & $0.693 \mathrm{~ns}$ & $-0.485 n s$ & $-0,889 * *$ & 1 \\
\hline & \multicolumn{3}{|c|}{$r(0.05: 7: 1)=0.754$} & \multicolumn{3}{|c|}{$\mathrm{r}(0.01 ; 7 ; 1)=0.874$} & & & \\
\hline
\end{tabular}

\section{Information :}

1. Maximum plant height

2. Maximum number of leaves

3. Amount of harvest per plant

4. Fresh fruit weight

5. Fruit length

6. Fruit diameter
7. Fruit oven-dry weight

8. Oven dry weight is stable

9. Harvest index

* = significantly affected $(\mathrm{p}<0.05)$

$* *=$ very significant $(\mathrm{p}<0.01)$

$\mathrm{ns}=$ not significantly affected $(\mathrm{p} \geq 0.05)$

Table 5

. Correlation coefficient value between plant variables (r) due to the influence of rabbit compost dose (K)

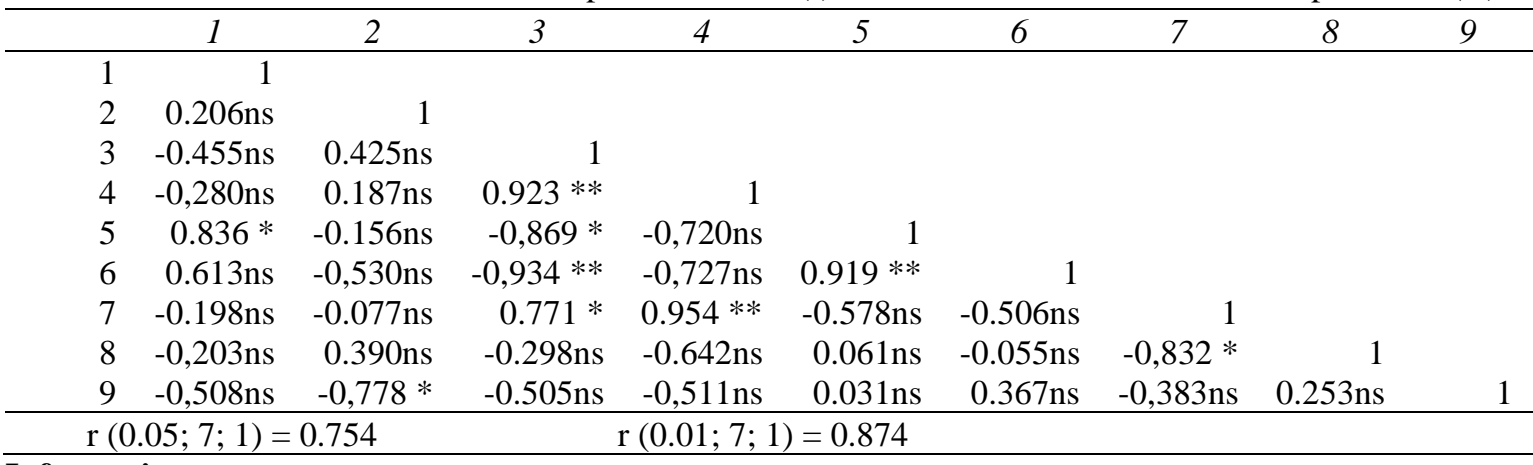

\section{Information :}

1. Maximum plant height

2. Maximum number of leaves

3. Amount of harvest per plant

4. Fresh fruit weight

5. Fruit length

6. Fruit diameter
7. Fruit oven-dry weight

8. Oven dry weight is stable

9. Harvest index

* = significantly affected $(\mathrm{p}<0.05)$

$* *=$ very significant $(\mathrm{p}<0.01)$

Ns $=$ not significantly affected $(\mathrm{p} \geq 0.05)$

The high yield of fruit fresh weight at a dose of 30 tons ha $^{-1}$ is due to the function of each nutrient associated with generative and vegetative growth. Because rabbit compost is one type of organic material that can be used to increase plant production, this is because giving rabbit manure can improve the physical, chemical, and biological properties of the soil because the organic matter is 
given to the soil so that it loosens the soil. A type of rabbit compost consisting of solid manure (feces) which becomes fertilizer to increase crop production. Rabbit manure contains $4.12 \% \mathrm{~N}$ nutrient, $\mathrm{P}$ 308.13 ppm, K 469.58 ppm, 4.12\% Organic C [8]. In line with [9], compost treatment of 30 tons per ha can provide the highest yield of fresh weight of red chilies.

The highest fresh fruit weight was obtained at the NPK fertilizer dose of $300 \mathrm{~kg} \mathrm{ha}^{-1}$ (D3), namely 2488.95 g. Fruit fresh weight increased by $18.23 \%$ when compared to the NPK fertilizer dose of 0 tons $\mathrm{ha}^{-1}$ (D0), which was $2104.87 \mathrm{~g}$. The high fresh weight of fruit was supported by the number of harvests per plant $(\mathrm{r}=0.923 * *)$ (Table 5). Nitrogen affects vegetative growth. Nitrogen is an essential element for plant growth. The role of nitrogen for plants is to stimulate overall plant growth, especially stems, branches, and leaves, and plays an important role in the formation of green leaves which are useful in the process of photosynthesis [10]. Elemental phosphorus $(\mathrm{P})$ is needed by plants in large quantities. Phosphorus helps to strengthen plant roots, helps root growth, and helps in shoot formation [11].

The element potassium $(\mathrm{K})$ plays a role during plant growth, namely resistance to disease [10]. Plants that have enough potassium so that the photosynthesis process and metabolic processes run well. Potassium plays a role in the process of opening and closing the stomata, supporting the process of root formation, strengthening leaves, flowers, and fruit so that they do not wither and fall easily [12].

\section{Conclusion}

The interaction between rabbit compost dose and NPK had no significant effect on all variables. The highest fresh fruit weight was obtained at the dose of rabbit compost 30 ton ha ${ }^{-1}$, namely 2463.64 $\mathrm{g}$, an increase of $16.09 \%$ when compared to the treatment without compost, namely $2084.30 \mathrm{~g}$. The highest fresh fruit weight was obtained at the NPK fertilizer dose of $300 \mathrm{~kg} \mathrm{ha}^{-1}$, namely $2488.95 \mathrm{~g}$. The fresh weight of the fruit increased by $18.23 \%$ when compared to the without NPK fertilizer, which was $2104.87 \mathrm{~g}$.

\section{Reference}

[1] Bannayan, M., Mortazagoldani, and MR Naderi. (2017). Growth Analysis of Pumpkin (Curcurbita pepo L.) Under Various Management Practices and Temperature Regimes. Agricultural Research \& Technology Open Journal 11 (1): 1-18.

[2] Asnijar., E. Kesumawati., And Syammiah. (2013). Effect of Bayfolan Varieties and Concentration on the Growth and Yield of Chili (Capsicum annum L.). Agrista Journal 17 (2): 60-65.

[3] Minnich, J. (2005). The Michigan Gardening Guide. University of Michigan Press. Michigan.

[4] Marsono and Sigit. (2001). Root fertilizers, types, and applications. Self-Help Spreader. Jakarta.

[5] Fahmi, N. (2014). Effect of Organic and Inorganic Fertilizers on Growth and Yield of Soybean (Glycine $\max ($ L.) Merril). J. Floratek 9: 53-62.

[6] Nahak N, Suarta M, and Mudra NLKS, (2018). The effect of SP-36 fertilizer and rabbit manure on the growth and yield of kailan (Brassica oleraceae var achepala). Gema Agro. 23 (2): 146 - 150.

[7] Situmeang, Y. P., Adnyana, I. M., Subadiyasa, I. N. N., \& Menit, I. N. (2015). Effect of Dose Biochar Bamboo, Compost, and Phonska on Growth of Maize (Zea Mays L.) In Dryland. International Journal on Advanced Science, Engineering and Information Technology, 5(6), 433-439.

[8] Khoir, MS, N. Herlina, Koesriharti, and M. Santoso. (2017). Effect of NPK Fertilizer and Rabbit Manure Compost on Growth and Yield of Carrot (Daucus carota L.). Journal of Plant Production. 5 (6): 1029 1034 
[9] Amaral, H. D. D. R., Situmeang, Y. P., \& Suarta, M. (2019). The effects of compost and biochar on the growth and yield of red chili plants. In Journal of Physics: Conference Series (Vol. 1402, No. 3, p. 033057). IOP Publishing

[10] Lingga, P., and Marsono. (2002). Instructions for Use of Fertilizers. Self-Help Spreader. Jakarta.

[11] Endah, HJ (2008). Make Flowering Ornamental Plants Diligent. PT Agro Media Pustaka Jakarta.

[12] Sari, ND (2009). The Effect of NPK Dosage and Types of Leaf Fertilizer on Growth and Production of Tuberose Flowers (Polianthes tuberosa L). Essay. Faculty of Agriculture, University of Lampung. 86 p. Agromedia Pustaka. Jakarta 